Cornell University Law School Scholarship@Cornell Law: A Digital Repository

\title{
Toward Internationally Regulated Goods: Controlling the Trade in Small Arms and Light Weapons
}

\author{
Asif Efrat \\ Visiting Professor, Cornell Law School, ae236@cornell.edu
}

Follow this and additional works at: http://scholarship.law.cornell.edu/facpub

Part of the International Trade Commons

\section{Recommended Citation}

Efrat, Asif, "Toward Internationally Regulated Goods: Controlling the Trade in Small Arms and Light Weapons" (2010). Cornell Law Faculty Publications. Paper 34.

http://scholarship.law.cornell.edu/facpub/34 


\title{
Toward Internationally Regulated Goods: Controlling the Trade in Small Arms and Light Weapons
}

\author{
Asif Efrat
}

\begin{abstract}
Contrary to the general trend of trade liberalization, specific goodssuch as small arms, drugs, and antiquities - have come under increasing international control in recent decades through a set of international regulatory agreements. This article offers a theoretical framework of government preferences on the international regulation of these goods. Departing from conventional models of trade policy, the theoretical framework introduces negative externalities, rather than protection, as the motivation for restricting trade; it also takes moral concerns into account. I test this framework empirically through an original survey of government views on international small-arms regulation. Based on interviewing officials from 118 countries, the survey reveals a large variation in government preferences that conforms to the theoretical expectations. I employ this variation to explain why the international regulation of small arms is weak, despite the fact that these are the deadliest weapons of all in terms of actual death toll.
\end{abstract}

The liberalization of markets and world trade is among the most important economic trends of the twentieth century. Since World War II, an ever-increasing number of countries have chosen to join the world trading system and lower protectionist barriers, thereby contributing to a significant growth of international trade. ${ }^{1}$ Yet the overall trend of increasing trade openness has been accompanied by an overlooked countertrend. While world trade has generally become more liberalized in recent decades, trade in specific goods has become more controlled and significantly less free. Indeed, governments have increasingly restricted and regulated commercial transactions involving a rapidly growing list of goods, from small arms to drugs to antiquities. They have done so through a set of international regulatory

For helpful comments and advice I thank Beth Simmons, Jack Goldsmith, Michael Hiscox, Andy Kydd, Lisa Martin, Jee Young Kim, participants in seminars and workshops at Harvard University, the editors of $I O$, and two anonymous reviewers. I also thank the Weatherhead Center for International Affairs for financial and logistic support; Yev Kirpichevsky for his help in conducting the survey; and Jeff Blossom and Giovanni Zambotti for assisting with the geographic analysis.

1. Milner and Kubota 2005. On economic liberalism generally, see Simmons, Dobbin, and Garrett 2006. 
agreements that established — rather than dismantled —obstacles to trade. The purpose of international regulation is to reduce the negative externalities for society resulting from free trade in these goods, such as fatalities and refugee flows stemming from the proliferation of small arms; crime associated with widespread drug abuse; and archaeological destruction caused by looting of antiquities. Yet despite the severity of the problems it addresses, international regulation has been extremely controversial. Governments have sharply disagreed about the extent of - and even the need for-international control of these goods, and at times the disagreements resulted in weak and ineffective regulation.

Consider small arms and light weapons. Small arms, such as rifles and pistols, are weapons for individual use. Light weapons, such as heavy machine guns, are designed for the use of a small crew. According to estimates, the death toll of small $\mathrm{arms}^{2}$ far exceeds that of any other weapon, including weapons of mass destruction. Worldwide, small arms cause at least 200,000 deaths annually in homicides, suicides, and unintentional shootings in nonconflict situations. They are also the weapons of choice in most present-day conflicts and are responsible for the vast majority of direct conflict deaths. The human toll of small arms also includes indirect conflict deaths due to disease, starvation, and displacement associated with armed violence. ${ }^{3}$ Furthermore, widespread gun violence inflicts various social and economic costs, including medical treatment, refugee flows, destruction of physical infrastructure, losses in productivity and foreign investment, political instability, trade obstruction, as well as disruption of health care and education. ${ }^{4}$ Small arms are widely used for terrorism, organized crime, and gang warfare. They also facilitate a large spectrum of human rights violations, including killing, rape, and torture. $^{5}$

In 1995 the United Nations (UN) launched a political process intended to combat the negative effects of small-arms proliferation ${ }^{6}$ and misuse. The primary agreement resulting from the UN small-arms process is the Program of Action to Prevent, Combat and Eradicate the Illicit Trade in Small Arms and Light Weapons in All Its Aspects $^{7}$ (Program of Action or PoA), adopted at a UN conference in July $2001 .^{8}$ The PoA intends to reduce the human suffering and devastating consequences caused by gun violence ${ }^{9}$ through a set of international guidelines for controlling small arms. Given their enormous toll, especially in Africa, one would

2. The term "small arms" in this article includes light weapons as well. The terms "small arms" and "guns" are used interchangeably.

3. See Small Arms Survey 2004, chap. 6, and 2005, chap. 9.

4. See Small Arms Survey 2006, chap. 8; and Cukier and Sidel 2006, chap. 2.

5. Report of the UN Secretary-General on Small Arms (S/2008/258), 17 April 2008.

6. According to estimates, there are at least 875 million small arms in circulation worldwide. Civilians own roughly 75 percent of this total (Small Arms Survey 2007, 39).

7. UN Document A/CONF.192/15.

8. United Nations Conference on the Illicit Trade in Small Arms and Light Weapons in All Its Aspects, New York, 9-20 July 2001.

9. Program of Action, Section I, para. 2-7. 
expect tight international control of small arms, based on a stringent agreement with a mechanism to ensure compliance. Yet the control of small arms as established by the PoA is far from such expectations. The PoA constitutes a loose framework that is hard to reconcile with the magnitude of the problem this document addresses; it also lacks key attributes of arms control agreements. First, the PoA has no legally binding force. Whereas arms control agreements typically take the shape of treaties, the PoA is merely a political declaration. Second, monitoring and verification arrangements are a cornerstone of arms control agreements such as the Nuclear Non-Proliferation Treaty (NPT); yet they are absent from the PoA. The PoA neither grants states the authority to monitor compliance, nor does it delegate verification authority to a third party. It merely asks states-on a voluntary basis - to provide information on implementation.

The PoA's weakness is also manifested in certain glaring substantive omissions. Although nonstate actors bear much of the blame for armed violence, the PoA fails to ban arms supply to unauthorized nonstate actors. Without ammunition, guns cannot threaten, wound, or kill; yet the PoA does not explicitly address ammunition, thereby dooming the efforts against gun violence to partial failure. A UN Review Conference met in 2006 to assess the implementation of the 2001 PoA and possibly establish additional commitments. However, the negotiations at the Review Conference failed, and the Conference ended without any outcome document.

As the PoA itself acknowledges, misuse of small arms "sustains conflicts, exacerbates violence, contributes to the displacement of civilians, ... and fuels crime and terrorism." ${ }^{10}$ Why, then, did governments choose to address such grave problems through a non-legally binding agreement that lacks a meaningful enforcement mechanism and avoids critical issues? Furthermore, how can one account for the weakness of the PoA compared with other arms-control agreements? Solving these puzzles requires an in-depth exploration of the conflicting preferences of governments over international small-arms regulation. ${ }^{11}$ The question, in other words, is why certain governments favor tight international regulation of the trade in small arms while others wish to maintain the trade uncontrolled.

Existing literature provides no answer to this question. Small arms have been "merely a footnote in scholarship ... on matters of proliferation and arms control," 12 although they kill far more people than any other weapon. The starting point to my analysis is therefore political economy models of trade policy. These models, however, focus on protection of industries as the motivation for trade barriers, while I seek to explain regulation aimed at curbing the negative externalities of trade. The article thus develops a theoretical framework of government prefer-

10. Ibid., para. 5 .

11. On the key role of state preferences in shaping international outcomes, see Moravcsik 1997.

12. Kinsella 2006, 100. The most significant source of information on small arms is a yearbook, Small Arms Survey, published since 2001 by the Graduate Institute of International Studies in Geneva, Switzerland. 
ences on international regulation that involves three theoretical innovations. One innovation is the replacement of protection with negative externalities as the main impetus for trade restrictions and control. Governments favor international regulation, first and foremost, to curb primary externalities - the trade's negative effects on their own countries. A second innovation is moral concerns about secondary externalities - the trade's negative effects on foreign countries-contrary to the focus of conventional trade models on material incentives. The third innovation is the government's role: not only a policy maker, but possibly a market actorexporter or consumer.

While the empirical focus of the article is small arms, its theoretical framework can illuminate the political conflict over other internationally regulated goods. I illustrate the theoretical argument by drawing on a variety of cases, including drugs, antiquities, counterfeit and pirated goods, and diamonds. Furthermore, the theoretical framework links government preferences to cooperation and explains why some controversies over international regulation resulted in a more robust cooperative outcome than did the controversy over small arms.

To assess the theoretical framework empirically, the article derives a set of hypotheses with respect to small arms and tests them through an original survey of government views on international small-arms regulation. Based on interviewing officials from 118 countries, the survey strongly supports the theoretical expectations and reveals a considerable variation in government preferences. Using this variation, I explain why the international regulation of small arms is weak.

\section{International Regulation and Its Causes}

In recent decades, governments around the world have facilitated commerce by lowering barriers to trade. Yet simultaneous with the general trend of trade liberalization, a countertrend has taken place: the conclusion of international regulatory agreements to control specific goods and to restrict-rather than facilitatecommercial transactions in these goods. The regulatory agreements subject the goods to internationally coordinated rules and practices and set barriers to their cross-border movement. For example, the Single Convention on Narcotic Drugs requires states "to limit exclusively to medical and scientific purposes the production, manufacture, export, import, distribution of, trade in, use and possession of drugs." ${ }^{13}$ The 1970 UNESCO Convention ${ }^{14}$ lays out rules concerning the import, export, and transfer of ownership of cultural property, aiming specifically at antiquities. The Kimberley Process Certification Scheme establishes a system of standardized certificates that accompany international shipments of rough diamonds.

13. Single Convention on Narcotic Drugs, 1961, Article 4(c).

14. Convention on the Means of Prohibiting and Preventing the Illicit Import, Export and Transfer of Ownership of Cultural Property, 1970. 
Why regulate certain goods internationally? While uncontrolled trade in these goods benefits exporters and consumers, it also generates negative externalities, that is, negative effects on society. These negative externalities may result from the production, sale, or use of the goods. Examples include gun homicide and drug-user crime (externalities from use); financing rebel military campaigns through proceeds from diamonds (externalities from sale); and archaeological destruction caused by unauthorized excavation of antiquities (externalities from production). The question, however, is why governments attempt to curb these externalities through international regulation and why national regulation is insufficient.

Consider small arms. Most countries have gun-control laws that regulate the import, sale, and possession of small arms. ${ }^{15}$ Why, then, is there a need for international regulation to reduce gun violence? The limited effectiveness of national gun regulation is a key reason. Restrictions on the import of small arms may exist on the books, but customs and border control often fail to detect and seize them; the increasing volume of trade in recent decades has further diminished the intensity and effectiveness of customs inspections. ${ }^{16}$ Regulating sale and possession of small arms is meaningful only if the police can apprehend the violators and courts' sentences are carried out; in many countries, this is not the case. Even developed countries often struggle to fully enforce gun regulation, let alone developing countries where trained and equipped law enforcement personnel are scarce. Without the required technological, operational, and financial resources, gun-control laws are merely words on paper. ${ }^{17}$

An alternative approach for reducing armed violence treats the roots of demand for small arms. Acquisition and possession of small arms have various causes, including lack of personal security; poverty and absence of educational and professional opportunities, especially among youth; pursuit of individual status; and sociocultural attitudes (association of guns with freedom, masculinity, and so on). Measures to lower demand may include court and police reform to enhance security, community policing, provision of education and employment, and stigmatization of guns and gun violence. ${ }^{18}$ Demand-side measures may indeed mitigate armed violence; however, they are costly and extremely complex, particularly for low-capacity governments.

Given the limited effectiveness of national gun control and the complexity of demand-side measures, curbing the negative externalities of small arms requires control at the source, that is, restraining small-arms exports. To place controls on the export of small arms, externalities-bearing countries turn to international regulation. International regulation augments the national controls of externalitiesbearing countries by inducing externalities-generating countries to establish adequate controls. Through international regulation, countries suffering gun violence seek

15. Cukier and Sidel 2006, chap. 7.

16. Raustiala 1999, 119-21.

17. Cukier and Sidel 2006, 135.

18. See Small Arms Survey 2006, chap. 6; and Cukier and Sidel 2006, chap. 6. 
to restrain arms-exporting countries and make them reduce the negative externalities of their exports.

The same rationale — shifting the burden of control—applies to other internationally regulated goods whose externalities, similar to those of small arms, originate outside those countries that bear them. International drug control aims to restrain drug-exporting countries and make up for the failure of drug-importing countries to restrict the inflow, possession, and use of drugs. Poor countries lack the resources to protect antiquities against looting and prevent their illegal export; international regulation of antiquities asks rich market-countries to control imports, since those countries' demand for antiquities fuels archaeological plunder. By requiring that all countries establish appropriate controls, especially those who generate the externalities, international regulation aligns national practices to curb the negative effects of the trade.

\section{Government Preferences on International Regulation: A Theoretical Framework}

Given its purpose-alleviating the harmful impact of trade-why is international regulation hotly contested among governments? Political economy models of trade policy, while a useful starting point, do not adequately capture the conflict of government preferences on international regulation. These models typically consider protection as the primary purpose of governmental restrictions on trade. ${ }^{19}$ Tariffs and nontariff barriers intend, first and foremost, to shield industries from loss of income caused by trade liberalization. With protection as the cornerstone, existing trade policy models are not suited for studying goods such as small arms and drugs. For these goods, the primary driver of trade restrictions is not protectionist demands from local industries that face import competition. Rather, it is the negative consequences of unregulated trade for society. The theoretical framework follows trade models by considering the influence of exporters and consumers, who benefit from liberalized trade; it departs from conventional trade analysis by introducing primary and secondary negative externalities as motivations for trade control.

Following Grossman and Helpman, ${ }^{20}$ I ascribe to the government an objective function that includes aggregate social welfare as well as support from interest groups. Concern for social welfare may reflect policymakers' personal choice among policy outcomes and their genuine interest in the well-being of domestic or foreign publics. Such concern may also aim to garner public support and enhance the government's prospects of political survival. The influences on the government

19. See, for example, the prominent model of Grossman and Helpman "Protection for Sale" (Grossman and Helpman 1994). On trade policy models generally, see Gawande and Krishna 2003; and Oatley 2006, chap. 4.

20. Grossman and Helpman 2001. 
are thus threefold: wishes of interest groups, wishes of the public, and policymakers' values.

\section{Exporters and Consumers}

Trade scholars have often attributed to exporters and consumers a preference for free trade. Exporters support trade liberalization to enhance foreign market access. Consumers favor free trade because it allows them to enjoy cheap imports and raises their real incomes. ${ }^{21}$ The exporters and consumers of the goods addressed here should have similar preferences. Some exporters may benefit from the anticompetitive effects of regulation, ${ }^{22}$ or they may hope that compliance with regulation would boost their reputation. Yet I expect that exporters would more often see international regulatory efforts as a threat to their commercial interests and would prefer to maintain freedom of trade. They indeed have good reasons for concern. At the extreme, international regulation could prohibit the trade altogether. For example, elimination of counterfeit and pirated goods is among the purposes of the Agreement on Trade-Related Aspects of Intellectual Property Rights (TRIPS). Regulation could also ban certain transactions, could slow or limit export through administrative requirements, and could increase the costs of production and transfer of the goods. For instance, the Single Convention on Narcotic Drugs requires any export of drugs to receive a separate export authorization; this authorization will be given only upon receipt of an import certificate issued by the authorities of the importing country. ${ }^{23}$ Such control measures do not bode well for exporters, as they make transactions slower and more likely to be blocked. Similarly, international regulation is detrimental to consumers, as it could raise the price of the goods, make them less easily accessible, and restrict their availability. For example, import controls could prevent consumers of antiquities - art dealers, museums, and private collectors - from acquiring antiquities that are not accompanied by documentation of legal export; these are, in fact, the majority of antiquities.

While exporters and consumers may oppose regulation, they vary in their ability to organize politically and in their influence on governments. When exporters or consumers are few in number or when the adverse impact of international regulation is sufficiently concentrated, these actors more easily overcome the collective action problem and organize for political action. Another obstacle to political activity, unique to the goods addressed here, is the illegal status of certain exporters and consumers. International regulation aims to make up for the insufficiency of national regulation; therefore, actors whose activities have been banned by preexisting national regulation cannot act through legitimate political channels and

21. See, for example, Gilligan 1997; and Baker 2003.

22. Stigler 1971.

23. Single Convention on Narcotic Drugs, 1961, Article 31. 
may resort to extra-legal means. For example, looters cannot legitimately and openly lobby against international control of antiquities that is motivated by the harm that they themselves cause; the same for gun-using criminals and terrorists. By contrast, legitimate exporters and consumers, such as arms manufacturers and museums, can lobby against international regulation.

In trade models the government sets trade policy but typically has no commercial interests of its own. ${ }^{24} \mathrm{I}$, however, consider the possibility that the government itself is an exporter, through a state-owned industry, or a consumer. In those cases, the government's direct stake in export or consumption provides particularly strong incentives to pursue uncontrolled or only weakly controlled trade.

Why would governments be more protective of state-owned exporters and more averse to international regulation than would be the case for privately owned exporters? One reason is that state-owned exporters generate revenue for governments. Uncontrolled trade could therefore mean higher government revenue. Another motivation for supporting state-owned exporters may be their association with goals greater than financial profit, such as national development or security. A third possible reason is that state-owned enterprises-"bureaucrats in business" 25 and part of the state apparatus-may enjoy easy access and close ties to policymakers, which facilitate lobbying.

There may also be less legitimate reasons for guarding the interests of stateowned exporters. Governments often use their control of state firms for patronage, that is, transfer of wealth to constituents in exchange for political support. Stateowned enterprises can provide various benefits to the government's supporters, such as excess employment and wages or location of production in politically desirable regions. ${ }^{26}$ In addition to political gains, state ownership may generate personal gains through bribes and channeling of revenues to politicians' pockets. The political and personal benefits yielded by state-owned exporters may increase governments' resistance to international regulation.

Similarly, one should take into account situations in which governments themselves consume the goods. The consumption of guns for domestic security and national defense is but one prominent example. By opposing international regulation, governments-as-consumers may wish to maintain their ability to obtain and use the goods.

\section{Primary Negative Externalities}

Primary externalities of trade are the negative effects on one's own country resulting from the production, sale, or use of the goods. These negative effects are felt

24. Branstetter and Feenstra's model of trade policy in China is an exception (Branstetter and Feenstra 2002).

25. World Bank 1995.

26. See Schleifer 1998; and Schleifer and Vishny 1998, chap. 9. 
mainly by the importing or exporting countries, but third countries may face them as well. For example, when country $A$ exports pirated goods to country $B$, the results are lost revenue to the legitimate author in country $C$ and the inhibition of future innovation.

Governments may care about the trade's negative effects for several reasons. First, uncontrolled trade could threaten and undermine social welfare. Policymakers concerned about political survival may therefore perceive a connection between addressing the externalities of trade and public support. Voters may vote governments out of office for failing to solve pressing social problems such as rampant gun violence or widespread drug abuse. Second, policymakers may be genuinely concerned about public welfare and act to curb the externalities out of a sense of duty and responsibility. Third, interest groups negatively affected by the trade may lobby governments to take action. ${ }^{27}$ Finally, uncontrolled trade may sometimes harm governments themselves. For example, supplying guns to rebel groups or financing these groups through sale of diamonds directly threatens governments' survival in power.

I expect two influences on governments' level of support for international regulation. First, support for international regulation will increase with the magnitude of the negative externalities. For example, the higher the rate of gun violence or drug abuse, the greater should be the government's support for international restraints on the trade in small arms or drugs. Second, support for international regulation will decrease as the government's ability to curb the trade increases. As explained above, governments that cannot control the trade and reduce its negative effects by themselves seek international regulation in order to establish controls at the other end of the chain. International regulation allows those governments to make up for their regulatory weakness. However, the greater the capacity of the importing (exporting) country to control the trade on its side, the less dependent it is on the control by the exporting (importing) country, and the lower its need for international regulation.

\section{Secondary Negative Externalities}

Concern about the negative effects of trade is not limited to governments whose countries face these effects. Certain governments, motivated primarily by values and moral principles, may care about the trade's negative impact on foreign countries. I term such impact secondary externalities, that is, externalities borne by countries other than one's own. In most cases, concern about secondary externalities stems from the negative humanitarian effects of the goods, such as the largescale killing and maiming associated with gun proliferation and conflict diamonds. Other goods raise nonhumanitarian concerns, such as preservation of cultural her-

27. An example is the initiation of TRIPS by the United States under the influence of American corporations seeking to curb counterfeiting and piracy; see Sell 2003. 
itage and historical knowledge in the case of antiquities. Whatever the reason for concern, the focus of secondary externalities is the harm to others, rather than any tangible negative effects on one's own country.

Why would governments hold other-regarding, morally inspired concerns? Such concerns may reflect policymakers' values. These concerns may also be a response to the perceived desire of elites and mass publics for an ethical foreign policy that includes curbing the externalities of trade abroad. From this standpoint, moral action allows policymakers to garner support and enhance their political power. ${ }^{28}$ In other cases, identifiable groups of principled actors lobby governments to initiate or participate in an international regulatory campaign. These actors may be domestic interest groups as well as transnational networks of nongovernmental organizations (NGOs) who share a value-based commitment to worldwide suppression of trade that they deem harmful and repugnant. For example, American missionaries concerned about China's opium problem played an important role in bringing the U.S. government to initiate international drug control in the early twentieth century ${ }^{29}$ in the late 1990s, a coalition of European NGOs entitled "Fatal Transactions" launched a campaign against conflict diamonds, which ultimately led to the Kimberley Process. ${ }^{30}$ How do these actors stimulate concern about the externalities of trade borne by foreign countries? Their main strategy involves educating policymakers and raising their awareness about the trade and its negative effects. To educate and raise awareness, these actors take advantage of their expertise and knowledge about the trade. They may provide and disseminate information through various techniques, such as meeting with policymakers, sending letters, providing oral and written testimonies, and publishing reports. A notable example is the reports of the NGO Global Witness, which raised awareness about the link between diamonds and civil wars and played an important role in the efforts to control the diamond trade. ${ }^{31}$

\section{Variation in Government Preferences and Implications for Cooperation}

I have identified four influences on government preferences: the anti-regulation push from exporters and consumers and the pro-regulation pull of primary and secondary negative externalities. Combining the four influences along two dimensions, as shown in Figure 1, leads one to expect a large variation in government preferences on international regulation.

At one extreme are governments concerned about primary or secondary negative externalities that do not face considerable anti-regulation pressure from export-

28. Such an interpretation is consistent with studies that tie ethical foreign policy endeavors to the public's views. See, for example, Lumsdaine 1993; and Bass 2008.

29. Taylor 1969, chap. 2.

30. Grant and Taylor 2004.

31. Global Witness 1998 and 2000. 
ers or consumers (Quadrant II). These governments likely support stringent international regulation, which offers them significant benefits-curbing the trade's negative externalities - at little cost. At the other extreme are governments that have little concern over the trade's negative effects on their own countries or on foreign countries but are strongly influenced by exporters or consumers who push for unregulated trade (Quadrant III). These governments are unlikely to support international regulation, which brings them little benefit in exchange for damage to exporters or consumers. Furthermore, international regulation requires these governments to bear the costs of improved law enforcement (for example, systems of export or import control) to the benefit of foreign countries. From these governments' point of view, international regulation unjustifiably and unnecessarily shifts onto them the burden of addressing problems that afflict others. Rather than enhancing control, they would prefer its relaxation or elimination.

\section{Influence of primary/secondary negative externalities}

\begin{tabular}{cc|c|c|}
\multicolumn{1}{c}{} & \multicolumn{2}{c}{ Low } & \multicolumn{1}{c|}{ High } \\
\cline { 3 - 4 } \multicolumn{1}{c|}{$\begin{array}{c}\text { Exporter/ } \\
\text { consumer } \\
\text { influence }\end{array}$} & Low & $\begin{array}{c}\text { I. } \\
\text { Weakly affected } \\
\text { governments } \\
\text { (Moderate regulation) }\end{array}$ & $\begin{array}{c}\text { II. } \\
\text { Pro-regulation } \\
\text { governments }\end{array}$ \\
\cline { 3 - 4 } & High & $\begin{array}{c}\text { III. } \\
\text { Anti-regulation } \\
\text { governments }\end{array}$ & $\begin{array}{c}\text { IV. } \\
\text { Cross-pressured } \\
\text { governments }\end{array}$ \\
& & (Support for regulation varies) \\
\hline
\end{tabular}

FIGURE 1. Expected government preferences on international regulation

A third group includes governments that are not concerned about primary or secondary externalities and do not face significant anti-regulation pressure from exporters or consumers (Quadrant I). These weakly affected governments have neither strong incentives to support international regulation nor reasons to oppose it. I expect them to adopt an intermediate position and favor moderate international regulation. Finally, a fourth group consists of cross-pressured governments (Quadrant IV). On the one hand, primary or secondary negative externalities motivate these governments to support international regulation. On the other hand, exporters or consumers push them toward unconstrained trade. These governments likely vary in their preferences. Their support for international regulation will increase the heavier the negative externalities are; support for regulation will decline the greater the influence of exporters or consumers is. 
The problem that emerges from this large heterogeneity of preferences is lack of shared interest in cooperation. Certain governments stand to benefit from international regulation; for other governments, however, international regulation is highly undesirable, as it yields large costs and only small gains, if any. Those governments who are made worse off would be reluctant to endorse stringent regulation, regardless of what other governments do-they simply have no incentive to cooperate. Given such considerable variation in preferences, the distribution of power plays a key role in shaping the cooperative outcome. Put differently, in the absence of shared interest and joint gains, the robustness of international regulation likely reflects the preferences of the powerful actors.

Weak governments favoring cooperation lack the capacity and leverage to bridge the preference gap. They cannot bring more powerful governments to accept regulation that is inconsistent with those governments' preferences. The resulting international regulation is thus likely to be weak. One possible manifestation of weakness is limited membership. Powerful externalities-generating countries may decline to join the regulatory agreement and thereby significantly diminish its utility. Antiquities regulation is a case in point. The attempt of developing countries rich in archaeology to stem antiquities looting through international regulation met with fierce resistance from governments of market countries. For those governments, international regulation would have adversely affected a thriving art market and would have harmed consumers of antiquities-those consumers whose demand motivated plunder. Regulation would also have entailed a costly law enforcement apparatus to prevent the import of looted material. Consequently, Britain, Germany, and Japan, among other market-countries, refused for decades to join the 1970 UNESCO Convention. ${ }^{32}$ Powerful governments opposed to regulation may also weaken the form and substance of the regulatory agreement and dilute its constraining impact. This has been the case with small arms. The Program of Action is a non-legally binding agreement that is loosely worded, leaving considerable discretion to governments; it also does not delegate authority to third parties for implementation, dispute resolution, or enforcement. As I elaborate below, the weakness of the PoA reflects the preferences of powerful actors such as the United States and China.

By contrast, powerful governments favoring cooperation can establish more robust regulation, given their ability to manipulate the incentives of weak governments who oppose international control. Consider TRIPS and the Single Convention on Narcotic Drugs, both spearheaded by the United States. Key externalitiesgenerating countries-exporters of counterfeit and pirated goods or drugs-have committed to these agreements, unlike the 1970 UNESCO Convention. Contrary to the PoA, these agreements are legally binding; establish precise and comprehensive commitments; and delegate authority to third parties (respectively, the Council for TRIPS and the World Trade Organization (WTO) Dispute Settlement 
Body; the Commission on Narcotic Drugs and the International Narcotics Control Board).

One mechanism that allows powerful governments to overcome the absence of shared interest is issue linkage, by which "multiple issues are included in the final settlement in an effort to create a balance where both sides gain enough to accept the costs." 33 Powerful governments can more easily establish an issue linkage than weak governments since powerful governments have more complementary issues to offer to offset losses. Furthermore, a linkage is likely to encounter resistance from governments influenced by domestic actors who oppose regulation. Powerful governments can pressure or induce resisting governments to accept the linkage. TRIPS, for example, met with opposition from developing countries reluctant to curb counterfeiting and piracy. In the Uruguay Round industrialized countries, led by the United States, linked TRIPS to agricultural and textile trade liberalization, which developing countries expected to benefit from. The threat of American trade sanctions further softened their opposition to TRIPS. ${ }^{34}$

A second mechanism that powerful governments may employ is coercion. Through rewards and punishments, powerful governments can increase the benefits of cooperation or the costs of noncooperation and thereby induce weaker governments to accept more robust regulation than they would have preferred. For example, in the early twentieth century, many countries opposed the U.S. endeavors for international drug control: colonial powers, in particular Britain whose colony in India produced opium; drug-producing countries such as Turkey and Peru; and countries whose pharmaceutical industry manufactured drugs, such as Germany and Switzerland. ${ }^{35}$ Pre-World War II, the conflicting preferences resulted in a limited international regulatory framework that fell short of the American ambition. Only as a superpower after World War II could the United States pressure other countries to accept more stringent regulation by tying drug control to economic and political support. ${ }^{36}$

Powerful pro-regulation governments can use coercion not only to establish tight international regulation but also to enhance compliance with it. The U.S. government publishes annual blacklists assessing the compliance of countries worldwide with their obligations to tackle drugs as well as counterfeiting and piracy. Countries judged to have failed demonstrably in meeting their obligations face the threat of punitive economic measures, such as withholding of aid and trade sanctions. ${ }^{37}$ In contrast, governments of developing countries plagued by gun violence or looting of antiquities can do little to pressure more powerful countries to comply with the relevant regulatory agreements.

33. Davis 2004, 156.

34. Sell 2003, 109-10.

35. McAllister 2000, 32-34, 66-67.

36. Bewley-Taylor 1999, 46-47, 60-61.

37. See ibid., 202-3; Mertha 2005; and Sell 2003, chap. 6. 


\section{Government Preferences on International Regulation of Small Arms: Hypotheses}

Building on the theoretical framework, this section develops a set of hypotheses about the international regulation of the small-arms trade. I first consider the antiregulation influence of exporters and consumers and then examine the pro-regulation influence of the trade's primary and secondary externalities.

\section{Exporters}

More than 1,200 companies in more than ninety countries are involved in some aspect of small-arms production. ${ }^{38}$ Of those, thirty to thirty-five countries export small arms with annual sales of more than $\$ 10$ million. The documented value of all small-arms exports in 2003 (based on reports to UN Comtrade) was about $\$ 2$ billion. According to estimates, the total annual value of the trade in small arms reaches $\$ 4$ billion. ${ }^{39}$

I expect small-arms exporters to pursue uncontrolled trade, since international regulation of small arms could adversely affect their business. A major concern for exporters is the possible establishment of international transfer-controls: common standards for controlling the export, import, and transshipment of small arms. These controls would reduce the likelihood of receiving the authorizations necessary for transferring arms and discontinue the practice of indiscriminate arms sales. For example, the competent national authorities would not approve an arms export if the arms might be used for human rights violations, fuel conflict, or to undermine development. From the exporter's point of view, such screening means lost income. Transparency on small-arms transfers is another regulatory measure with a possible detrimental effect on arms exports: it would increase the pressure on exporters to avoid transferring arms that are at risk of being misused. Transparency could also result in a more careful scrutiny of requests for export licenses and a lower rate of approvals. Furthermore, international regulation might increase the costs of production. For example, an obligation to mark small arms with laser, intended to facilitate the identification of any weapon, could impose a financial burden on exporters.

For many exporters, international controls on small arms could mean obstruction of sales and lost revenue. To what extent can exporters shape the government's preference? In most countries the small-arms industry includes a handful of exporters, often only one or two major firms, thereby reducing the costs of organizing politically and avoiding a collective action problem. Another relevant characteristic of the arms industry is the prevalence of state ownership. In seventeen out of thirty-two exporting countries included in this study, the state is the sole or main owner of the small-arms industry, and this ownership structure likely affects gov-

38. Small Arms Survey 2004, 7.

39. Ibid. 2006, chap. 3. 
ernments' calculations. I expect governments to be especially protective of stateowned arms exporters and less supportive of international regulation that could threaten their commercial interests.

Yet "[a]rms sales are far more than an economic occurrence ... arms sales are foreign policy writ large." 40 Throughout the Cold War, both superpowers used arms transfers to establish leverage and to bolster friendly regimes or undermine unfriendly ones. ${ }^{41}$ Today, politically motivated arms transfers still constitute a tool of statecraft at the hands of arms-exporting countries, including the United States, China, and Israel..$^{42}$ International regulation threatens to constrain this political use of arms. Transparency on small-arms transfers may discourage arms supply to rebel groups or repressive governments. A ban on arms supply to unauthorized nonstate actors could also significantly hamper the political utility of arms transfers. Governments of exporting countries who are interested in maintaining this foreign policy tool are unlikely to support international regulation of small arms.

In sum, the two considerations-commercial interests of the arms industry reinforced by the political use of arms transfers-point governments of exporting countries in the same direction: preference for unregulated trade in small arms.

H1: Governments of arms-exporting countries, in particular where the smallarms industry is state-owned, are less likely to support international regulation of small arms.

\section{Consumers}

Consumers of small arms are numerous and varied. Armed groups-such as rebels, criminals, and terrorists-have an obvious interest in opposing regulation. However, these are precisely the consumers that governments would like to prevent from obtaining arms. Given that their activity is illegal and, in fact, is the motivation for regulation, I do not expect their preference for free trade in arms to affect government preferences.

What about law-abiding civilian gun owners? The UN small-arms process focuses on armed groups, rather than civilians. However, civilians may be affected as well if regulation raises prices. Moreover, some countries, such as Mexico, believe that easy access of civilians to arms makes those arms more likely to fall into the wrong hands and increases the risk of gun violence. Therefore, these countries would have liked to establish international guidelines restricting the possession and use of small arms by civilians (for example, prohibition on civilian possession of automatic weapons and limitation on the number of weapons that civilians may possess). Civilian gun owners are thus likely to oppose international regulation of

40. Pierre 1982, 3. Emphasis in original.

41. See ibid; and Krause 1991.

42. See Byman and Cliff 1999; and Klieman 1992. 
small arms. For the most part, however, gun owners are not politically organized. In only a handful of countries, most notably the United States, do gun owners have politically active lobbies that guard their interests. Such lobbies-the National Rifle Association (NRA) being the most prominent-may pressure governments to resist international regulation.

Governments themselves are major consumers of small arms for internal and external security. I argue that nondemocratic governments in particular are less likely to favor international small-arms regulation because of the centrality of domestic repression for their social control and political survival. Numerous studies have shown that nondemocracies either engage in overt repression and abuse of personal integrity rights or establish a permanent threat of repression through a state police machinery. ${ }^{43}$ In the absence of alternative noncoercive means for social control, such as popular legitimacy of the regime, nondemocratic governments rely on the threat or use of forceful measures to ensure the population's obedience and stifle dissent. Released from constraints on the domestic use of force, such as free elections and judicial review, they also have greater opportunity to engage in repression with impunity.

Since forceful repression - threatened or realized - is essential for the functioning and survival of nondemocratic governments, their dependence on the supply of small arms is greater than that of democracies. Democratic governments obviously require small arms as well for maintaining law and order and for national defense, but they typically do not draw a direct link between arms supply and the regime's domestic viability. All else equal, the ramifications of regulating the smallarms trade are less far-reaching and threatening for democracies than they are for nondemocratic governments, whose ability to govern relies on their repressive capacity. It is this reliance that makes nondemocracies more sensitive than democracies to any interference with their arms supply. If international regulation makes guns and ammunition less easily available, the survival of a nondemocratic regime may be imperiled. ${ }^{44}$ Moreover, the dependence on arms leaves nondemocratic governments vulnerable to pressure. External actors could potentially use international regulation to restrict the supply of arms to these governments.

H2: Nondemocratic governments are less likely to support international regulation of small arms compared with democracies.

\section{Primary Negative Externalities}

The theoretical framework has suggested that governments' support for international regulation should increase with the magnitude of the externalities that

43. See, for example, Poe, Tate, and Keith 1999; and Regan and Henderson 2002.

44. Lai and Morey 2006 make a similar argument regarding the sensitivity of nondemocracies to reduction in military aid. 
their countries bear. How can one measure the primary negative externalities of small arms? Uncontrolled trade in small arms has both immediate and distant effects. Homicide, crime, and various forms of collective violence are immediate results of gun availability and misuse. ${ }^{45}$ I use homicide rates to measure the immediate negative effects of small arms. ${ }^{46}$ Small-arms proliferation also has more distant effects, such as refugee flows, damage to public utilities, and disruption of education. I use refugee outflows to measure the wider negative effects of small arms.

H3: High homicide rates or large refugee outflows increase governments' support for international regulation of small arms.

Governments' support for international regulation also depends on their capacity to control small arms, and the two should be negatively correlated. The weaker the capacity for national control, the greater the government's reliance on international regulation. Controlling gun import and possession requires both trained personnel and technical equipment; it entails effective customs, police, and licensing authorities. These are less likely to exist in poor countries with underdeveloped bureaucratic infrastructure and weak law enforcement. Unable to control small-arms import and possession, governments of poor countries are likely to support international regulation in order to tackle the problem at the source by curbing small-arms exports.

H4: The poorer the country, the greater its government's support for international regulation of small arms.

\section{Secondary Negative Externalities}

Secondary externalities are the externalities borne by foreign countries. For small arms, the source of concern about secondary externalities is the devastating humanitarian effects of gun proliferation and misuse, from fatalities to refugee flows to stifled development. Governments with a humanitarian foreign policy agenda, such as those of Japan, Canada, and many European countries, are thus likely to treat small arms as a pressing humanitarian concern. I expect them to support international regulation of small arms in order to curb gun violence abroad.

I use provision of humanitarian aid as an indication of humanitarian motivation.

H5: The greater its provision of humanitarian aid, the stronger the government's support for international regulation of small arms.

45. Cukier and Sidel 2006, chap. 2.

46. I use overall homicide rates rather than gun homicide rates since reliable data on the latter are unavailable for nearly half the countries included in this study. 
In addition, I control for the origin of the legal system. Recent research has shown that common law countries are more cautious about making international legal commitments. ${ }^{47}$ Common law should therefore be associated with weaker support for international regulation of small arms.

\section{Empirical Testing}

I test the hypotheses through an original survey of government views on the international regulation of small arms. The survey included interviews with officials from 118 countries, conducted in June-July 2006 in New York during and immediately following the UN Review Conference on Small Arms (with the exception of eight telephone interviews and one email interview). Respondents came from ministries of foreign affairs, defense, justice, and interior as well as from police and military forces. In most cases one official was interviewed from each country; in twelve cases two or three officials from the same country were interviewed jointly. All respondents received the questionnaire in advance to allow them to prepare for the interview. The questionnaire asked respondents to provide their countries' views on the UN small-arms process. The questions addressed the 2001 Program of Action as well as proposed regulatory measures not included in the PoA. See the Appendix for selected survey questions; Table A1 lists the countries included in the survey.

I first paint the overall picture through statistical and geographic analysis. I then shed light on the variation in government preferences by discussing the responses to the survey questions. Respondents were promised anonymity; the text below identifies them only by country.

\section{Survey Results: Statistical Analysis}

The theoretical framework has suggested that government preferences would vary from weak to strong support for international regulation (see Figure 1). To construct this continuum with respect to small arms, I combine three survey questions whose subject was the general characteristics of the UN small-arms process: the scope of the process, the level of obligation: political or legal commitments, and the compliance mechanism (Q3, Q4, and Q6 in the questionnaire). Combining the three questions created a 0 to 5 scale of government support for international regulation (REGULATION). 0 indicates a government preference for weak regulation: a limited UN process that addresses the illicit small-arms trade without regulating the legal trade in small arms, political rather than legal commitments, and the existing compliance mechanism (voluntary self-reporting on implementation); 5 indi- 
cates government support for strong regulation: a comprehensive UN process covering the legal small-arms trade, coupled with legally binding commitments and a stronger compliance mechanism.

In addition to the composite variable REgULATION, I use two individual questions as dependent variables. The question on the scope of the UN process (Q3) is the most important question in the survey, because it asked directly whether the small-arms trade should be regulated. SCOPE ranges from 0 to 2: 0 means a government preference for limiting the UN process to the illicit trade and excluding the legal trade; 2 means a preference for addressing both the legal and the illicit trade. The question about transparency $(\mathrm{Q} 8)$ represents those survey questions concerned with specific regulatory measures. Respondents were asked whether their country supported the establishment of an international transparency mechanism for small-arms transfers. TRANSPARENCY ranges from 0 to 2: $0=$ lack of support for transparency; 2 = full support for transparency.

Measures and data sources for the explanatory variables are as follows.

- ARMS EXPORTER. Since the impact of state-owned arms exporters is expected to be different from that of privately owned exporters, I use two dummy variables. The first indicates whether (1) or not (0) a country has state-owned arms exporters; the second indicates whether (1) or not (0) a country has privately owned arms exporters. Only the variable for stateowned exporters achieved statistical significance and is shown in Tables 1 and $2 .{ }^{48}$

- DEMOCRACY. The variable ranges from -10 (autocracy) to 10 (democracy). ${ }^{49}$

- REFUGEES. Number of refugees by country of origin in 2005..$^{50}$

- Homicide Rate. Recorded homicide per 100,000 inhabitants in 2005 or most recent year available. ${ }^{51}$

- LN GDP PER CAPITA. Log of a country's gross domestic product (GDP) per capita in $2005 .^{52}$

- hUMANITARIAN-AID PROVISION. The share of humanitarian aid in bilateral Official Development Assistance that a country provided in 2006. ${ }^{53}$

48. Small Arms Survey 2006 and the NISAT database of small-arms transfers were used to identify countries that export small arms worth at least $\$ 10$ million annually (based on 2003 sales data). Data on the ownership of the small-arms industry are from Jane's World Defence Industry 2004; Kiss 2004; Weidacher 2005; and Saferworld 2002.

49. The source is Polity IVd.

50. The source is UNHCR 2006.

51. The source is United Nations Surveys of Crime Trends and Operations of Criminal Justice Systems; and Cukier and Sidel 2006.

52. The source is IMF World Economic Outlook Database 2006.

53. The source is OECD Statistics. 
- COMMON LAW. The variable indicates whether (1) or not (0) a country's legal system is based on the common law. ${ }^{54}$

Table 1 presents the results of an ordered logit analysis. Models 1 to 3 use REFUGEES to measure the negative externalities of small arms; Models 4 to 6 use HOMICIDE RATE. The results provide strong evidence for all five hypotheses. Government support for international regulation increases with DEMOCRACY (H2), HUMANITARIAN-AID PROVISION (H5), as well as REFUGEES and HOMICIDE RATE (H3). In line with H1, STATE-OWNED ARMS EXPORTER reduces government support for international regulation. Consistent with H4, LN GDP PER CAPITA is negatively associated with support for regulation, indicating the need of poor countries to make up for their low capacity for gun control through international regulation. As expected, COMMON LAW is negatively correlated with government support for international regulation.

Table 2 shows large substantive effects of the different variables on government preferences over the international regulation of small arms.

Changing the DEMOCRACY score from perfect autocracy to perfect democracy increases the expected probability of support for strong regulation (REGULATION $=5$ ) by 0.52 . For example, when DEMOCRACY $=-10$ and all other variables are at their mean, $\operatorname{Pr}($ REgulation $=5)$ is 0.11 ; when DEMOCRACY $=10, \operatorname{Pr}($ REGUlATION $=5$ ) is 0.63 . This is a very considerable substantive effect. STATE-OWNED ARMS EXPORTER has a large effect as well, reducing the probability of support for strong regulation by 0.29 . Raising REFUGEES from 0 to Liberia's refugees increases the probability of support for strong regulation by 0.26 . Shifting from France's homicide rate to Brazil's much-higher rate increases the probability of a preference for strong regulation by 0.36. Lowering LN GDP PER CAPITA from that of Switzerland to that of Mali leads to an increase of 0.45 in the probability of favoring strong regulation. Increasing HUMANITARIAN-AID PROVISION from 0 to Norway's level raises the probability of support for strong regulation by 0.41 . COMMON LAW is associated with a decrease of 0.23 in the probability of support for strong regulation.

\section{Robustness Checks}

As an alternative measure of small-arms exporters, I used the logged ratio of smallarms exports to total exports. ${ }^{55}$ Consistent with $\mathrm{H} 1$, the higher the ratio of smallarms exports to total exports, the lower the support for international regulation (significant at 0.1 level).

Effective gun control requires bureaucratic infrastructure for licensing, registration, and so forth. Instead of GDP per capita, national capacity to control guns

54. The source is La Porta et al. 1999.

55. The value of small-arms exports in 2003 is from Small Arms Survey 2006; the total value of exports in 2003 is from WTO Trade Statistics. 
TABLE 1. Determinants of government preferences on international regulation of small arms

\begin{tabular}{|c|c|c|c|c|c|c|}
\hline Variables & $\begin{array}{c}\text { Model } 1 \\
\text { REGULATION }\end{array}$ & $\begin{array}{l}\text { Model } 2 \\
\text { SCOPE }\end{array}$ & $\begin{array}{c}\text { Model } 3 \\
\text { TRANSPARENCY }\end{array}$ & $\begin{array}{c}\text { Model } 4 \\
\text { REGULATION }\end{array}$ & $\begin{array}{l}\text { Model } 5 \\
\text { SCOPE }\end{array}$ & $\begin{array}{c}\text { Model } 6 \\
\text { TRANSPARENCY }\end{array}$ \\
\hline STATE-OWNED ARMS EXPORTER & $\begin{array}{c}-1.383 * * * \\
(0.513)\end{array}$ & $\begin{array}{c}-1.403 * * \\
(0.653)\end{array}$ & $\begin{array}{l}-3.079 * * * \\
(0.83)\end{array}$ & $\begin{array}{c}-0.925^{*} \\
(0.506)\end{array}$ & $\begin{array}{l}-1.1^{*} \\
(0.663)\end{array}$ & $\begin{array}{l}-2.555 * * * \\
(0.751)\end{array}$ \\
\hline DEMOCRACY & $\begin{array}{l}0.138^{* * * *} \\
(0.033)\end{array}$ & $\begin{array}{l}0.156 * * * \\
(0.042)\end{array}$ & $\begin{array}{l}0.198 * * * \\
(0.047)\end{array}$ & $\begin{array}{l}0.15^{* * * *} \\
(0.038)\end{array}$ & $\begin{array}{l}0.148 * * * \\
(0.049)\end{array}$ & $\begin{array}{l}0.185 * * * \\
(0.049)\end{array}$ \\
\hline REFUGEES & $\begin{array}{c}5.05 \mathrm{e}-06^{*} \\
(2.78 \mathrm{e}-06)\end{array}$ & $\begin{array}{c}7.43 \mathrm{e}-06^{*} \\
(4.36 \mathrm{e}-06)\end{array}$ & $\begin{array}{l}7.4 \mathrm{e}-06 \\
(7.58 \mathrm{e}-06)\end{array}$ & & & \\
\hline HOMICIDE RATE & & & & $\begin{array}{c}0.06 * * \\
(0.027)\end{array}$ & $\begin{array}{c}0.057 * \\
(0.032)\end{array}$ & $\begin{array}{c}0.031 \\
(0.036)\end{array}$ \\
\hline LN GDP PER CAPITA & $\begin{array}{c}-0.445^{* * *} \\
(0.165)\end{array}$ & $\begin{array}{c}-0.403 * * \\
(0.201)\end{array}$ & $\begin{array}{c}-0.392 \\
(0.25)\end{array}$ & $\begin{array}{r}-0.205 \\
(0.199)\end{array}$ & $\begin{array}{r}-0.166 \\
(0.254)\end{array}$ & $\begin{array}{c}-0.233 \\
(0.262)\end{array}$ \\
\hline HUMANITARIAN-AID PROVISION & $\begin{array}{l}14.911 * * \\
(6.494)\end{array}$ & $\begin{array}{l}21.967 * * \\
(9.368)\end{array}$ & $\begin{array}{c}28.493^{*} \\
(16.325)\end{array}$ & $\begin{array}{c}13.86^{* *} \\
(6.448)\end{array}$ & $\begin{array}{l}19.482 * * \\
(9.29)\end{array}$ & $\begin{array}{l}26.116 \\
(16.305)\end{array}$ \\
\hline COMMON LAW & $\begin{array}{l}-1.006^{* *} \\
(0.44)\end{array}$ & $\begin{array}{c}-0.824^{*} \\
(0.497)\end{array}$ & $\begin{array}{l}-0.85 \\
(0.711)\end{array}$ & $\begin{array}{l}-1.095^{* *} \\
(0.511)\end{array}$ & $\begin{array}{c}-0.952 * \\
(0.583)\end{array}$ & $\begin{array}{c}-0.821 \\
(0.714)\end{array}$ \\
\hline Cut 1 & -5.926 & -3.395 & -6.06 & -3.5 & -1.035 & -4.394 \\
\hline Cut 2 & -5.016 & -2.847 & -4.407 & -2.477 & -0.462 & -2.736 \\
\hline Cut 3 & -4.264 & & & -1.59 & & \\
\hline Cut 4 & -3.464 & & & -0.9 & & \\
\hline Cut 5 & -2.797 & & & -0.004 & & \\
\hline Observations & 118 & 118 & 114 & 94 & 94 & 92 \\
\hline Prob $>\chi 2$ & 0.00 & 0.00 & 0.00 & 0.00 & 0.00 & 0.00 \\
\hline Log-likelihood & -161.881 & -87.276 & -50.899 & -133.453 & -69.047 & -46.009 \\
\hline
\end{tabular}

Notes: Ordered logit regressions. Standard errors in parentheses. *significant at $10 \%$; **significant at $5 \%$; ** significant at $1 \%$. Independent variable for privately owned arms exporter not reported. 
TABLE 2. Substantive effects on government support for international regulation of small arms

\begin{tabular}{|c|c|c|c|c|c|c|}
\hline & $\begin{array}{c}\Delta \mathrm{Pr} \\
(\mathrm{REG} .=0)\end{array}$ & $\begin{array}{c}\Delta \mathrm{Pr} \\
(\mathrm{REG} .=1)\end{array}$ & $\begin{array}{c}\Delta \mathrm{Pr} \\
(\mathrm{REG} .=2)\end{array}$ & $\begin{array}{c}\Delta \mathrm{Pr} \\
(\mathrm{REG} .=3)\end{array}$ & $\begin{array}{c}\Delta \operatorname{Pr} \\
(\text { REG. }=4)\end{array}$ & $\begin{array}{c}\Delta \mathrm{Pr} \\
(\mathrm{REG} .=5)\end{array}$ \\
\hline STATE-OWNED ARMS EXPORTER: No $\rightarrow$ Yes & $\begin{array}{c}0.11 \\
(0.02,0.27)\end{array}$ & $\begin{array}{c}0.09 \\
(0.02,0.19)\end{array}$ & $\begin{array}{c}0.08 \\
(0.02,0.16)\end{array}$ & $\begin{array}{c}0.03 \\
(-0.01,0.08)\end{array}$ & $\begin{array}{c}-0.03 \\
(-0.1,0.01)\end{array}$ & $\begin{array}{c}-0.29 \\
(-0.45,-0.09)\end{array}$ \\
\hline DEMOCRACY: $-10 \rightarrow 10$ & $\begin{array}{c}-0.27 \\
(-0.5,-0.09)\end{array}$ & $\begin{array}{c}-0.17 \\
(-0.28,-0.05)\end{array}$ & $\begin{array}{c}-0.11 \\
(-0.2,-0.04)\end{array}$ & $\begin{array}{c}-0.03 \\
(-0.1,0.03)\end{array}$ & $\begin{array}{l}0.05 \\
(0,0.12)\end{array}$ & $\begin{array}{c}0.52 \\
(0.32,0.68)\end{array}$ \\
\hline REFUGEES: $0 \rightarrow$ Liberia & $\begin{array}{c}-0.04 \\
(-0.09,0)\end{array}$ & $\begin{array}{c}-0.04 \\
(-0.1,0)\end{array}$ & $\begin{array}{c}-0.06 \\
(-0.13,0)\end{array}$ & $\begin{array}{c}-0.08 \\
(-0.16,0)\end{array}$ & $\begin{array}{c}-0.04 \\
(-0.12,0)\end{array}$ & $\begin{array}{c}0.26 \\
(-0.01,0.48)\end{array}$ \\
\hline HOMICIDE RATE: France $\rightarrow$ Brazil & $\begin{array}{c}-0.06 \\
(-0.13,-0.01)\end{array}$ & $\begin{array}{c}-0.07 \\
(-0.15,-0.01)\end{array}$ & $\begin{array}{c}-0.1 \\
(-0.2,-0.02)\end{array}$ & $\begin{array}{c}-0.08 \\
(-0.17,-0.01)\end{array}$ & $\begin{array}{c}-0.04 \\
(-0.15,0.02)\end{array}$ & $\begin{array}{c}0.36 \\
(0.06,0.61)\end{array}$ \\
\hline LN GDP PER CAPITA: Switzerland $\rightarrow$ Mali & $\begin{array}{c}-0.15 \\
(-0.34,-0.03)\end{array}$ & $\begin{array}{c}-0.12 \\
(-0.25,-0.02)\end{array}$ & $\begin{array}{c}-0.11 \\
(-0.21,-0.02)\end{array}$ & $\begin{array}{c}-0.08 \\
(-0.14,-0.02)\end{array}$ & $\begin{array}{c}0.01 \\
(-0.03,0.06)\end{array}$ & $\begin{array}{c}0.45 \\
(0.12,0.7)\end{array}$ \\
\hline HUMANITARIAN-AID PROVISION: $0 \rightarrow$ Norway & $\begin{array}{c}-0.05 \\
(-0.11,-0.01)\end{array}$ & $\begin{array}{c}-0.06 \\
(-0.12,-0.01)\end{array}$ & $\begin{array}{c}-0.09 \\
(-0.17,-0.01)\end{array}$ & $\begin{array}{c}-0.12 \\
(-0.21,-0.01)\end{array}$ & $\begin{array}{c}-0.09 \\
(-0.18,0)\end{array}$ & $\begin{array}{c}0.41 \\
(0.04,0.63)\end{array}$ \\
\hline COMMON LAW: No $\rightarrow$ Yes & $\begin{array}{c}0.07 \\
(0.01,0.16)\end{array}$ & $\begin{array}{c}0.06 \\
(0.01,0.14)\end{array}$ & $\begin{array}{c}0.06 \\
(0.01,0.14)\end{array}$ & $\begin{array}{c}0.05 \\
(0.01,0.09)\end{array}$ & $\begin{array}{c}-0.01 \\
(-0.05,0.02)\end{array}$ & $\begin{array}{c}-0.23 \\
(-0.4,-0.05)\end{array}$ \\
\hline
\end{tabular}

Notes: The table reports the change in expected probability of each value of REGULATION resulting from changes in the explanatory variables. Calculations were conducted using Clarify (Tomz, Wittenberg, and King 2001) based on Model 1 in Table 1, with the exception of homicide RATE (Model 4). 95\% confidence intervals in parentheses. 
was measured using the Bureaucratic Quality indicator from International Country Risk Guide. Like GDP per capita, bureaucratic quality is negatively correlated with support for international regulation (significant at 0.01 level).

To examine whether a country's general inclination for cooperation influences the regulation preference, a variable indicating IO membership was included. ${ }^{56}$ The variable was not statistically significant and did not affect the results.

I also considered the possibility that preferences on international regulation of small arms simply reflect domestic approaches to gun control. This, however, is not the case. For example, Finland and Switzerland have relatively liberal gun laws domestically and high levels of civilian gun possession, ${ }^{57}$ yet they prefer strong international regulation of small arms (REGULATION $=5$ for both countries). By contrast, gun control in China and Egypt is very strict, yet both countries prefer weak international regulation of small arms (REGULATION $=0$ and 1 , respectively).

\section{Cross-Regional Variation}

To examine cross-regional variation in preferences, I recoded REGULATION into a three-level measure: preference for weak, moderate, or strong international regulation of small arms (corresponding to the values $0-1,2-3,4-5$ of REGULATION). Figure 2 shows government preferences on the world map.

Sub-Saharan Africa and Latin America are the regions in which small arms create the largest negative externalities. For example, gun homicide rate in South Africa in 2002 was 26.1 (per 100,000) and the equivalent rate for Colombia was 51.8 (compared with 0.35 in Norway). As the regions most negatively affected by gun proliferation and misuse, Sub-Saharan Africa and Latin America strongly support the international regulation of small arms. Europe, motivated primarily by humanitarian concerns about gun violence worldwide, is also largely supportive of strong international regulation.

The Middle East, by contrast, favors weak international regulation. This preference stems from the nondemocratic nature of most Middle Eastern governments coupled with the limited negative externalities of small arms on their territories. For example, gun homicide rate in Egypt in 2005 was merely 0.14. The region is also host to three major exporting countries with state-owned arms industries: Egypt, Iran, and Israel.

Small arms cause much more limited problems in East and South Asia than in Sub-Saharan Africa. For example, gun homicide rate in Thailand in 2002 was 3.22. Moreover, governments in East and South Asia have, on average, greater capacity to tackle gun violence than African governments. Hence their cautious approach

56. The number of international organizations in which a country was a member in 2000, Correlates of War data.

57. Small Arms Survey 2007, 47. 
to international regulation. In addition, China, India, and Pakistan are major exporting countries with state-owned arms industries.
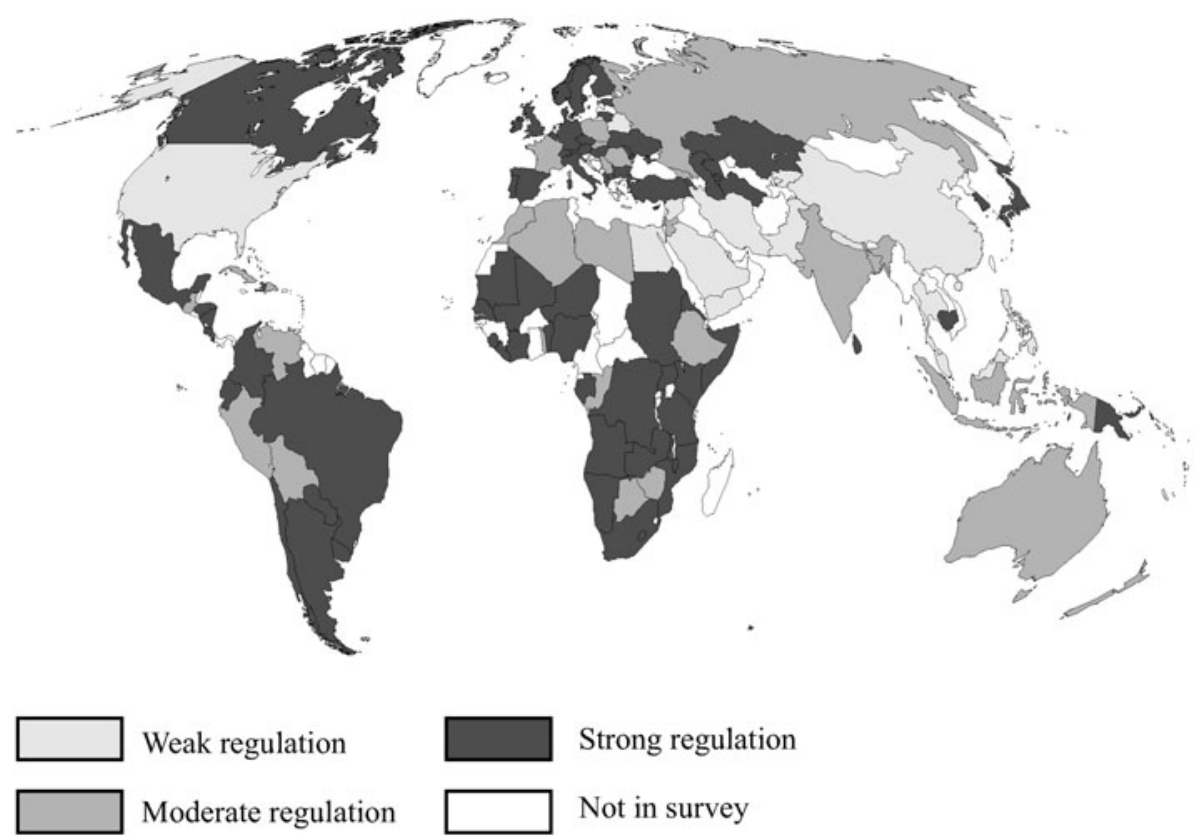

Weak regulation

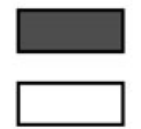

Strong regulation

Moderate regulation

Not in survey

FIGURE 2. Government preferences on international regulation of small arms

The Pacific holds an intermediate position. The region has suffered the negative effects of small arms availability and misuse, but stringent regulation might overburden the tiny bureaucracies of the small island states. The common law tradition also weakens the region's support for international regulation.

In addition to cross-regional variation, some variation exists within regions as well. Japan and South Korea, both aid donors with a humanitarian dimension to their foreign policy, are more supportive of regulation than most countries in their region. So is Sri Lanka, who faces larger negative externalities than its neighbors due to a prolonged civil war. Algeria, Libya, and Morocco are indirectly affected by the gun problems of their African neighbors; hence, they favor stronger regulation than other Arab countries. France, with a large state-owned arms industry, exhibits a more cautious approach to international regulation compared with other Western European countries.

\section{Survey Results: Qualitative Analysis}

The survey reveals a large variation in preferences on international regulation of small arms that conforms to the theoretical expectations. Figure 3 illustrates this 
variation. Countries are placed in the matrix according to the corresponding influences on their preferences. Each country's REGULATION score, based on the survey data, is in parentheses.

\section{Influence of primary/secondary negative externalities}

\begin{tabular}{|c|c|c|c|}
\hline \multirow{3}{*}{$\begin{array}{c}\text { Exporter/ } \\
\text { consumer } \\
\text { influence }\end{array}$} & & Low & High \\
\hline & Low & $\begin{array}{c}\text { I. } \\
\text { Weakly affected } \\
\text { Indonesia (3), Peru (3), } \\
\text { Botswana (3) }\end{array}$ & $\begin{array}{c}\text { II. } \\
\text { Pro-regulation } \\
\text { Colombia (5), Somalia (5), } \\
\text { Japan (5), Sweden (4) }\end{array}$ \\
\hline & High & $\begin{array}{c}\text { III. } \\
\text { Anti-regulation } \\
\text { China (0), Egypt (1), } \\
\text { Syria (1),Belarus (0) }\end{array}$ & $\begin{array}{c}\text { IV. } \\
\text { Cross-pressured } \\
\text { Austria (5), India (2), } \\
\text { Cuba (2), United States (1) }\end{array}$ \\
\hline
\end{tabular}

Note: The country's Regulation score is in parentheses.

FIGURE 3. Variation in government preferences on international regulation of small arms

The model predicts strong support for international regulation from governments that face the primary negative externalities of small arms. This is indeed the case with Colombia (REGUlation $=5$ ), Somalia ( REgulation $=5$ ), and other countries in Sub-Saharan Africa and Latin America that suffer from rampant gun violence. Respondents from these countries emphasized the high costs of gun violence in terms of human life, crime, instability, and stifled development. According to the Kenyan respondent, the weapon of mass destruction in his country is not a nuclear bomb; rather, it is the Kalashnikov. These countries therefore support stringent international regulation of small arms. The Liberian respondent, for example, explained that "by controlling arms, by reducing arms, by ensuring that arms are not in the hands of nonstate actors but in the hands of responsible people ... Liberia will enhance, protect, and consolidate its peace." In particular, these countries are in favor of regulating the legal small-arms trade. They believe that the legal and the illicit trade are two sides of the same coin since most illicit weapons begin their lives as legal weapons. Therefore, these countries reject attempts to distinguish between the legal and the illicit trade and argue that a focus on the illicit trade alone would undermine the UN process. In their view, regulation of the legal trade is necessary for holding arms suppliers accountable and for preventing the provision of arms to actors who would misuse them. 
Respondents also expressed disappointment over the political nature of the Program of Action, arguing that a legally binding instrument would have been more effective. The Brazilian respondent, for example, maintained that an issue as important, complex, and sensitive as small arms should have been addressed through legally binding commitments. Similarly, the respondents from Mexico and Tanzania, among others, identified the PoA's compliance mechanism as a fundamental weakness. They expressed their governments' interest in strengthening this mechanism and exerting more pressure on countries to comply. African respondents particularly emphasized their governments' inability to tackle gun violence, making it imperative to restrain arms suppliers through international regulation. The Somali respondent, for example, explained that the meager resources of his government and Somalia's large territory make the disarming of militias extremely difficult, and therefore international controls are necessary. African respondents asserted, however, that the PoA does not establish effective restraints, especially in light of its failure to ban arms supply to unauthorized nonstate actors and the neglect of ammunition.

The model predicts that governments concerned about secondary externalities would support stringent international regulation. This is indeed the case with Japan $($ REGUlATION $=5)$, Sweden ( REgUlation $=4)$, and other countries that provide humanitarian aid. Respondents from these countries explained their governments' interest in international regulation primarily in humanitarian and moral terms or as part of their concern for global security or human security. The British respondent, for example, explained that "the major motivator is a moral motivator ... proliferation of small arms is causing major havoc in the developing world ... from a moral position, we want that stopped." Similar to countries bearing primary externalities, humanitarian-motivated countries tend to prefer comprehensive regulation that would address the legal as well as the illicit trade in small arms. They support legally binding commitments, a stronger compliance mechanism than the existing one, and various regulatory measures, including transparency and international transfer-controls.

The model predicts that governments guarding the interests of state-owned arms exporters would favor weak international regulation of small arms. This is indeed the case with China (REgUlation $=0)$, Egypt (REgulation $=1)$, and other countries with state-owned arms exporters. Respondents from these countries expressed interest in maintaining freedom of trade and exhibited concern about the implications of international regulation, especially what they regarded as unnecessary constraints on legitimate arms-exports. Accordingly, they argued that international regulation should be limited to the illicit trade in small arms, leaving the regulation of the legal trade to national authorities. They also considered strengthening the PoA's compliance mechanism unnecessary, unfeasible, or even counterproductive. The Egyptian and Iranian respondents, for instance, maintained that stronger enforcement would be unrealistic since many countries lack the capacity to implement the PoA. Respondents also held strong reservations on the proposals to establish a transparency mechanism for small-arms transfers or a ban on arms transfers 
that might be used for human rights violations. They considered such measures unnecessary or impractical.

The model predicts that governments guarding the interests of consumers would favor weak international regulation. This is indeed the case with Syria (REGULATION $=1$ ), Belarus (REGULATION $=0$ ), and other nondemocratic governments who are anxious to secure their ability to acquire arms and to prevent international regulation from becoming a means of pressure. Respondents representing these governments emphasized that countries relying on arms imports should enjoy access to arms and that international regulation should not compromise their security and ability to maintain law and order. Specifically, respondents voiced their concern that a link between the legal and the illicit trade might be abused for political purposes, allowing external actors to meddle with their countries' national security. The Syrian respondent, for example, argued that such a link would be used to deprive Syria of arms because of its ties to Iran and Palestinian groups. Therefore, respondents insisted that the UN process should be limited to the illicit trade and exclude the legal trade. They also vehemently opposed the establishment of transfer controls that, in their view, might be misused for political pressure by denying arms to governments labeled as "human rights violators."

The model predicts that weakly affected governments would support moderate international regulation. Indonesia, Peru, and Botswana do not export small arms; they face relatively low-scale problems of gun violence and thus derive limited benefits from the UN small-arms process. As expected, they favor moderate international regulation of small arms (REGULATION $=3$ for all three countries).

Consistent with the theoretical expectation, cross-pressured governments vary in their preferences. Certain governments balance the interests of exporters visá-vis their country's gun problem or concerns about gun violence abroad. When the arms industry is private, the government's interest in protecting it is weaker than for a state-owned industry. In these cases, pro-regulation incentives may prevail over the commercial interests and tilt the balance toward support for regulation. For example, the respondent from Austria (REGUlATION $=5$ ) indicated that the arms industry had expressed concerns about international regulation, yet these were dispelled by a government pursuing humanitarian foreign policy goals. By contrast, India balances the desire to mitigate its terrorism problem against the interests of a state-owned arms industry, resulting in a preference for moderate international regulation (REGULATION $=2$ ). Cuba holds a similar preference. The Cuban government cannot fully control inflows of guns and hopes that international regulation will alleviate this problem, but not at the price of risking the government's own arms supply.

The U.S. government is also cross-pressured. Controlling small arms could reduce the risk to American soldiers overseas and is consistent with the humanitarian aspect of U.S. foreign policy. Yet international regulation could potentially harm American gun manufacturers and could restrict the United States' ability to provide arms to nonstate actors. Most importantly, small-arms consumers-civilian gun owners represented by the NRA-perceive international regulation as a threat to their pos- 
session and use of guns. ${ }^{58}$ The result of these conflicting incentives, especially the powerful influence of the NRA, is weak American support for international regulation of small arms (REGULATION $=1$ ). On the scope of the UN process, the United States holds an intermediate position, arguing that the process should deal primarily with the illicit trade, yet recognizing that certain aspects of the legal trade, such as export control, should be addressed as well. However, the United States believes that the small-arms process should be based on political rather than legal commitments, and sees no need for strengthening the existing compliance mechanism. In the American view, implementation of the PoA depends on the political will of governments; legal commitments or a stronger compliance mechanism will not necessarily generate such will. The United States particularly opposes the establishment of international rules on civilian possession of arms, seeing this as a domestic issue. It also opposes a comprehensive ban on arms transfers to unauthorized nonstate actors and argues for ascertaining the legitimacy and responsibility of end-users on an individual basis. Most importantly, the United States insists that the UN process exclude ammunition, in contrast to the view held by many other countries and expressed succinctly by the respondent from Sri Lanka: "A gun without ammunition is just a stick."

\section{Additional Evidence}

Government statements before and during the $2001 \mathrm{UN}$ conference that adopted the PoA provide a check on the survey data. These public statements dovetail nicely with survey responses. Governments in Latin America and Sub-Saharan Africa issued statements largely supportive of the UN process. Senegal, for example, advocated giving "absolute priority" to the fight against small-arms circulation and called for a Program of Action that would include legally binding commitments. ${ }^{59}$ Consistent with the survey data, the American and Chinese statements were less enthusiastic. The Unites States indicated its opposition to "measures that would constrain legal trade and legal manufacturing of small arms" and expressed a preference for non-legally binding commitments.$^{60}$ China emphasized the importance of confining the UN small-arms process to the illicit trade alone. ${ }^{61}$

The adoption of the PoA in July 2001 overshadowed another agreement on small arms adopted only two months earlier: Protocol against the Illicit Manufacturing of and Trafficking in Firearms, Their Parts and Components and Ammunition, supplementing the United Nations Convention against Transnational Organized Crime (Firearms Protocol). As survey respondents noted, the Firearms Protocol had been

58. LaPierre 2006.

59. Statement by Senegal during the General Debate of the First Committee, 55th Session of the UN General Assembly, 4 October 2000.

60. Statement by the United States during the UN Conference on Small Arms, 9 July 2001.

61. Statement of the Representative of China at the First Preparatory Committee for the UN Conference on Small Arms, 29 February 2000. 
marginalized compared with the PoA. This marginalization is consistent with the large variation in government preferences documented here. Countries favoring weak international regulation, especially major arms-exporting countries such as China, were willing to accept the non-legally binding PoA; however, they have declined to ratify the legally binding Firearms Protocol. In fact, ratification of the Protocol follows the cross-regional preference variation depicted in Figure 2. The Protocol has been ratified primarily by countries in Africa, Latin America, and Europe and has achieved few ratifications in the Middle East, East and South Asia, and the Pacific; the United States has also not ratified the Protocol. Firearms Protocol ratification and REGULATION-the survey-based measure of government preferences-are positively correlated (Spearman correlation coefficient is 0.24 , significant at 0.01 level).

\section{Preference Variation and Small-Arms Cooperation}

In the absence of legally binding force and a meaningful enforcement mechanism, the PoA could hardly be considered an appropriate international response to the devastating consequences of small-arms proliferation and misuse. The respondent from Tanzania put it bluntly: this document "does not force anyone to do anything." The reason is the large variation in government preferences, which several survey respondents indeed highlighted as a primary obstacle to international regulation. They pointed out that governments vary dramatically in their interests, priorities, and expectations. Some are concerned about the daily killing of innocent victims, while others guard the commercial interests of arms exporters. For the African governments, the small-arms process is a top priority, while certain Arab governments consider the process to be a distraction from their prioritynuclear disarmament. Many governments would like to address the issues of civilian possession and nonstate actors, which are a taboo for others. African respondents decried the unwillingness of arms-exporting countries to take full responsibility for the harm they generate and their reluctance to accept international controls.

Why did the preference variation pose an insurmountable obstacle, resulting in a weak international regulatory framework in 2001 and a deadlock at the 2006 Review Conference? First, international small-arms regulation aims to restrain armsexporting countries and requires their cooperation. Since international regulation rejected by arms-exporting countries would be nearly futile, these countries enjoy superior bargaining power. Second, the small-arms conferences in 2001 and 2006 were consensus-based-an agreement required the consent of all participating countries - and this decision rule further amplified exporting countries' bargaining advantage. Arms-exporting countries favoring weak regulation effectively held a veto power, which allowed them to secure outcomes that met their preferences. Survey respondents noted the advantage of a consensus-based approach-having all countries on board-alongside a major drawback: the process reflects the lowest common denominator. Third, and most importantly, the distribution of power 
favors regulation opponents. The African governments, the primary proponents of the UN small-arms process, lack the resources and bargaining power necessary to establish a successful issue linkage; nor is the exercise of coercion a realistic option for them. The cooperative outcome therefore conforms to the preference for weak regulation of countries such as the United States, China, Egypt, and Iran. The governments of these countries sought an agreement that would reflect concern about the grave problem of small arms, but would lack teeth. The PoA was indeed that.

As explained above, the weakness of the PoA contrasts with TRIPS and the international drug regime. In those cases, pro-regulation governments exploited their power advantage to make noncooperative governments accept stringent international control. The PoA is also weak compared with arms control agreements such as the NPT-a legally binding treaty that includes monitoring and verification arrangements. First, the establishment of the two agreements posed different cooperation problems. The NPT involved a set of distributional concerns: at the Treaty's inception, much uncertainty surrounded the distribution of gains. ${ }^{62}$ In the case of small arms, by contrast, the problem is absence of shared interest in cooperation. For certain governments, international regulation of small arms yields no gains; rather, it makes them worse off. Consequently, the conflict of preferences is more intense than was the case with the NPT. Second, the NPT rewarded countries that agreed to forgo nuclear weapons through transfer of peaceful nuclear technology. The African governments could not offer an equivalent reward to overcome resistance to small-arms regulation and had to accept a cooperative outcome that did not fulfill their wishes and expectations.

\section{Conclusion}

The trade in goods such as small arms, drugs, and antiquities and the problems it raises are hardly a new phenomenon. Yet, the increasing openness of the global economy has given a significant boost to these kinds of trade. Economic liberalization and improvements in communication and transportation have facilitated international transactions in these goods ${ }^{63}$ and have increased the harm associated with them worldwide. From civil wars sustained by the supply of small arms to the social costs of widespread drug abuse, the negative externalities of trade constitute a major threat to human welfare.

Nevertheless, these kinds of trade have been understudied by international relations scholars and have received little attention in the trade literature. Scholars who have examined them have typically done so within a crime framework. The provision of arms to rebels and terrorists, drug trafficking, and similar transnational flows have been seen as part of an illicit and clandestine global economy in

62. Koremenos 2001, 305-8.

63. See Andreas 2002; and Raustiala 1999. 
which the main actors are criminal groups and networks. ${ }^{64}$ Accordingly, efforts against these commercial activities have been studied as policing and crimecontrol endeavors. ${ }^{65}$ This article has offered a new theoretical perspective on the subject that normalizes these types of trade. Instead of treating them as illegal activities that take place in the shadows, outside the parameters of the mainstream economy, I have sought to integrate them into mainstream political economy analysis by employing the lens of trade regulation. This new analytical lens provides valuable tools to examine the motivations and conduct of societal actors and governments. Furthermore, contrary to the focus of existing accounts on criminal actors, this article has shifted the attention to the legitimate links in the chain that are the targets of international regulation-actors such as arms manufacturers who sell guns indiscriminately, indifferent to the negative effects of their business. Ultimately, while the trade in small arms, drugs, and similar goods has crime and law enforcement aspects, it does not follow an entirely distinct criminal logic. Analysis of trade regulation yields a better understanding of political conflicts and of cooperative outcomes than does thinking in terms of crime.

This article has also suggested that trade policy is shaped by a larger variety of influences than those the trade policy literature has highlighted: trade's negative externalities for society, governments' own interests as exporters or consumers, and moral concerns about welfare abroad. Moral concerns have indeed occupied an increasing role in trade policymaking in recent years. ${ }^{66}$ Notable examples are the inclusion of human rights provisions in preferential trade agreements ${ }^{67}$ and the controversy over developing countries' access to affordable AIDS medications. Yet trade policy models remain interest-based, failing to capture the growing weight of normative convictions, values, and moral beliefs in trade policy. As human rights issues seep into the WTO and as governments increasingly seek to reconcile trade and human rights policies, trade policy analysis can no longer be based solely on material factors while overlooking the impact of values and moral views. Both dimensions - the material and the ideational-shape many of the contemporary debates over trade, and if our lens remained focused on the former and insensitive to the latter, we would miss an important part of the picture.

The article's main policy implication concerns the merit of nonglobal cooperation. While global cooperation may be desirable, conflicting government preferences could render it weak. In those circumstances, limited cooperation between governments with homogeneous preferences offers a second-best alternative. Especially within a region or subregion, where government preferences are relatively aligned, cooperation may have better chances of success than globally. Indeed, while the UN small-arms process has failed to establish meaningful global coop-

64. Examples include Friman 2009; and Naím 2005.

65. Andreas and Nadelmann 2006.

66. Aaronson and Zimmerman 2008.

67. Hafner-Burton 2005. 
TABLE A1. Countries included in the survey

\begin{tabular}{|c|c|c|c|}
\hline Albania & Ecuador & Lithuania & Serbia \\
\hline Algeria & Egypt & Macedonia & Sierra Leone \\
\hline Angola & Eritrea & Malawi & Slovakia \\
\hline Argentina & Estonia & Malaysia & Slovenia \\
\hline Armenia & Ethiopia & Mali & Somalia \\
\hline Australia & Fiji & Malta & South Africa \\
\hline Austria & Finland & Mauritania & Spain \\
\hline Bangladesh & France & Mexico & Sri Lanka \\
\hline Belarus & Gabon & Moldova & Sudan \\
\hline Belgium & Gambia & Morocco & Sweden \\
\hline Benin & Georgia & Mozambique & Switzerland \\
\hline Bolivia & Germany & Namibia & Syria \\
\hline Botswana & Guatemala & Nepal & Tanzania \\
\hline Brazil & Haiti & Netherlands & Thailand \\
\hline Britain & Honduras & New Zealand & Togo \\
\hline Bulgaria & Hungary & Nicaragua & Turkey \\
\hline Cambodia & India & Niger & Turkmenistan \\
\hline Canada & Indonesia & Nigeria & Uganda \\
\hline Chile & Iran & Norway & Ukraine \\
\hline China & Ireland & Pakistan & United States \\
\hline Colombia & Israel & Рариа New Guinea & Uruguay \\
\hline Congo, Democratic Republic of & Italy & Paraguay & Venezuela \\
\hline Congo, Republic of & Japan & Peru & Yemen \\
\hline Costa Rica & Jordan & Philippines & Zambia \\
\hline Cote d'Ivoire & Kazakhstan & Poland & Zimbabwe \\
\hline Croatia & Kenya & Portugal & \\
\hline Cuba & Korea, Republic of & Qatar & \\
\hline Cyprus & Kyrgyzstan & Romania & \\
\hline Czech Republic & Lesotho & Russia & \\
\hline Denmark & Liberia & Saudi Arabia & \\
\hline Dominican Republic & Libya & Senegal & \\
\hline
\end{tabular}

eration, African governments have made progress in curbing gun violence through several regional and subregional agreements. ${ }^{68}$ Assistance from donor countries to governments in Africa and elsewhere has also facilitated a variety of measures, such as implementation of gun legislation and weapon destruction. These limited initiatives do not fully compensate for the weakness of global cooperation and the reluctance of arms-exporting countries to establish proper controls, but they certainly help mitigate a devastating problem. When global cooperation is thwarted by conflicting government preferences, smaller-scale collaboration among likeminded governments could prove more fruitful.

68. For example, ECOWAS Convention on Small Arms and Light Weapons, Their Ammunition and Other Related Materials, adopted in 2006; and the Nairobi Protocol for the Prevention, Control and Reduction of Small Arms and Light Weapons in the Great Lakes Region and the Horn of Africa, adopted in 2004. 


\section{Appendix. Selected Survey Questions ${ }^{69}$}

Q3. Some believe that the UN small-arms process should address only the illicit trade in small arms. Others believe that the process should address both the legal and the illicit trade. What is [country name] position?

Q4. The Program of Action is a political rather than legally binding document. Is [country name] content with the PoA being a political document, or would [country name] have preferred a legally binding PoA?

Q6. The Program of Action includes a mechanism for compliance and implementation that is based on biennial meetings of states to consider the Program's implementation and on voluntary submission of national reports. Is [country name] content with the existing mechanism, or would [country name] have preferred a stronger mechanism or a weaker one?

Q8. Does [country name] support the establishment of a transparency mechanism for small-arms transfers, such as the expansion of the UN Register of Conventional Arms to include small arms?

Q11. Does [country name] support the establishment of an international rule prohibiting small-arms transfers to unauthorized nonstate actors?

Q13. Does [country name] support the establishment of an international rule prohibiting the transfer of small arms if the arms might be used for violation of human rights?

\section{References}

Aaronson, Susan Ariel, and Jamie M. Zimmerman. 2008. Trade Imbalance: The Struggle to Weigh Human Rights Concerns in Trade Policymaking. New York: Cambridge University Press.

Andreas, Peter. 2002. Transnational Crime and Economic Globalization. In Transnational Organized Crime and International Security: Business as Usual?, edited by Mats R. Berdal and Mónica Serrano, 37-52. Boulder, Colo.: Lynne Rienner.

Andreas, Peter, and Ethan Nadelmann. 2006. Policing the Globe: Criminalization and Crime Control in International Relations. New York: Oxford University Press.

Baker, Andy. 2003. Why Is Trade Reform So Popular in Latin America? A Consumption-Based Theory of Trade Policy Preferences. World Politics 55 (3):423-55.

Bass, Gary J. 2008. Freedom's Battle: The Origins of Humanitarian Intervention. New York: Knopf.

Bewley-Taylor, David R. 1999. The United States and International Drug Control, 1909-1997. London: Continuum.

Branstetter, Lee G., and Robert C. Feenstra. 2002. Trade and Foreign Direct Investment in China: A Political Economy Approach. Journal of International Economics 58 (2):335-58.

Byman, Daniel L., and Roger Cliff. 1999. China's Arms Sales: Motivations and Implications. Santa Monica, Calif.: RAND.

Cukier, Wendy, and Victor W. Sidel. 2006. The Global Gun Epidemic: From Saturday Night Specials to $A K-47 s$. Westport, Conn.: Praeger.

Davis, Christina L. 2004. International Institutions and Issue Linkage: Building Support for Agricultural Trade Liberalization. American Political Science Review 98 (1):153-69.

Efrat, Asif. 2009. Governing Guns, Opposing Opium: The Politics of Internationally Regulated Goods. Ph.D. diss., Harvard University.

69. The complete questionnaire is in Efrat 2009, chap. 3. 
Elkins, Zachary, Andrew T. Guzman, and Beth A. Simmons. 2006. Competing for Capital: The Diffusion of Bilateral Investment Treaties, 1960-2000. International Organization 60 (4):811-46.

Friman, H. Richard, ed. 2009. Crime and the Global Political Economy. Boulder, Colo.: Lynne Rienner.

Gawande, Kishore, and Pravin Krishna. 2003. The Political Economy of Trade Policy: Empirical Approaches. In Handbook of International Trade, edited by E. Kwan Choi and James Harrigan, 213-50. Malden, Mass.: Wiley Blackwell.

Gilligan, Michael J. 1997. Empowering Exporters: Reciprocity, Delegation, and Collective Action in American Trade Policy. Ann Arbor: University of Michigan Press.

Global Witness. 1998. A Rough Trade: The Role of Companies and Governments in the Angolan Conflict. Available at $\langle$ http://www.globalwitness.org/media_library_detail.php/90/en/a_rough_trade $\rangle$. Accessed 7 October 2009.

- 2000. Conflict Diamonds: Possibilities for the Identification, Certification and Control of Diamonds. Available at $\langle$ http://www.globalwitness.org/media_library_detail.php/86/en/conflict_ diamonds $\rangle$. Accessed 7 October 2009.

Grant, J. Andrew, and Ian Taylor. 2004. Global Governance and Conflict Diamonds: The Kimberley Process and the Quest for Clean Gems. The Round Table 93 (375):385-401.

Grossman, Gene M., and Elhanan Helpman. 1994. Protection for Sale. American Economic Review 84 (4):833-50.

- 2001. Special Interest Politics. Cambridge, Mass.: MIT Press.

Hafner-Burton, Emilie M. 2005. Trading Human Rights: How Preferential Trade Agreements Influence Government Repression. International Organization 59 (3):593-629.

Jane's World Defence Industry. 2004. Coulsdon, England: Jane's Information Group.

Kinsella, David. 2006. The Black Market in Small Arms: Examining a Social Network. Contemporary Security Policy 27 (1):100-17.

Kiss, Yudit. 2004. Small Arms and Light Weapons Production in Eastern, Central, and Southeast Europe. Small Arms Survey Occasional Paper No. 13. Available at /http://www.smallarmssurvey.org/files/ sas/publications/o_papers_pdf/2004-op13-se_europe-production.pdf $\rangle$. Accessed 7 October 2009.

Klieman, Aharon S. 1992. Double-Edged Sword: Israel Defense Exports as an Instrument of Foreign Policy (in Hebrew). Tel Aviv, Israel: Am Oved.

Koremenos, Barbara. 2001. Loosening the Ties that Bind: A Learning Model of Agreement Flexibility. International Organization 55 (2):289-325.

Krause, Keith. 1991. Military Statecraft: Power and Influence in Soviet and American Arms Transfer Relationships. International Studies Quarterly 35 (3):313-36.

Lai, Brian, and Daniel S. Morey. 2006. Impact of Regime Type on the Influence of U.S. Foreign Aid. Foreign Policy Analysis 2 (4):385-404.

LaPierre, Wayne. 2006. The Global War on Your Guns: Inside the UN Plan to Destroy the Bill of Rights. Nashville, Tenn.: Thomas Nelson.

La Porta, Rafael, Florencio Lopez-de-Silanes, Andrei Shleifer, and Robert Vishny. 1999. The Quality of Government. Journal of Law, Economics, and Organization 15 (1):222-79.

Lumsdaine, David Halloran. 1993. Moral Vision in International Politics: The Foreign Aid Regime, 1949-1989. Princeton, N.J.: Princeton University Press.

McAllister, William B. 2000. Drug Diplomacy in the Twentieth Century: An International History. London: Routledge.

Mertha, Andrew C. 2005. The Politics of Piracy: Intellectual Property in Contemporary China. Ithaca, N.Y.: Cornell University Press.

Milner, Helen V., and Keiko Kubota. 2005. Why the Move to Free Trade? Democracy and Trade Policy in the Developing Countries. International Organization 59 (1):107-43.

Moravcsik, Andrew. 1997. Taking Preferences Seriously: A Liberal Theory of International Politics. International Organization 51 (4):513-53.

Naím, Moisés. 2005. Illicit: How Smugglers, Traffickers, and Copycats are Hijacking the Global Economy. New York: Doubleday.

Oatley, Thomas. 2006. International Political Economy: Interests and Institutions in the Global Economy. $2 \mathrm{~d}$ ed. New York: Longman. 
Pierre, Andrew J. 1982. The Global Politics of Arms Sales. Princeton, N.J.: Princeton University Press. Poe, Steven C., C. Neal Tate, and Linda Camp Keith. 1999. Repression of the Human Right to Personal Integrity Revisited: A Global Cross-National Study Covering the Years 1976-1993. International Studies Quarterly 43 (2):291-313.

Raustiala, Kal. 1999. Law, Liberalization and International Narcotics Trafficking. NYU Journal of International Law and Politics 32:89-145.

Regan, Patrick M., and Errol A. Henderson. 2002. Democracy, Threats and Political Repression in Developing Countries: Are Democracies Internally Less Violent? Third World Quarterly 23 (1):119-36.

Saferworld. 2002. Arms Production, Exports, and Decision-Making in Central and Eastern Europe. June 2002. London: Saferworld. Available at 〈http://www.saferworld.org.uk/publications.php/68/ arms_production_exports_and_decision_making_in_central_and_eastern_europe $\rangle$. Accessed 7 October 2009.

Schleifer, Andrei. 1998. State Versus Private Ownership. Journal of Economic Perspectives 12 (4):133-50.

Schleifer, Andrei, and Robert W. Vishny. 1998. The Grabbing Hand: Government Pathologies and Their Cures. Cambridge, Mass.: Harvard University Press.

Sell, Susan K. 2003. Private Power, Public Law: The Globalization of Intellectual Property Rights. Cambridge: Cambridge University Press.

Simmons, Beth A. 2009. Mobilizing for Human Rights: International Law in Domestic Politics. New York: Cambridge University Press.

Simmons, Beth A., Frank Dobbin, and Geoffrey Garrett. 2006. Introduction: The International Diffusion of Liberalism. International Organization 60 (4):781-810.

Small Arms Survey [Graduate Institute of International Studies, Geneva]. Various Years. Oxford/ Cambridge: Oxford University Press/Cambridge University Press.

Stigler, George J. 1971. The Theory of Economic Regulation. Bell Journal of Economics and Management Science 2 (1):3-21.

Taylor, Arnold H. 1969. American Diplomacy and the Narcotics Traffic, 1900-1939: A Study in International Humanitarian Reform. Durham, N.C.: Duke University Press.

Tomz, Michael, Jason Wittenberg, and Gary King. 2001. CLARIFY: Software for Interpreting and Presenting Statistical Results. Version 2.0. Available at /http://gking.harvard.edu/clarify/docs/ clarify.html $\rangle$. Accessed 7 October 2009.

United Nations High Commissioner for Refugees (UNHCR). 2006. 2005 Global Refugee Trends. Available at $\langle$ http://www.unhcr.org/statistics/STATISTICS/4486ceb12.pdf $\rangle$. Accessed 7 October 2009.

Weidacher, Reinhilde. 2005. Behind a Veil of Secrecy: Military Small Arms and Light Weapons Production in Western Europe. Small Arms Survey Occasional Paper 16. Available at 〈http:// www.smallarmssurvey.org/files/sas/publications/o_papers_pdf/2005-op16-west_europe.pdf $\rangle$. Accessed 7 October 2009.

World Bank. 1995. Bureaucrats in Business: The Economics and Politics of Government Ownership. New York: Oxford University Press. 